\title{
Preparation of Biofuel from Palm Oil Catalyzed by Ammonium Molybdate in Homogeneous Phase
}

\author{
Sepehr Sadighi*, Seyed Kamal Masoudian Targhi \\ Research Institute of Petroleum Industry (RIPI), Catalysis Research Division, \\ P.O. Box 14665137, Tehran, Iran
}

Received: $3^{\text {rd }}$ May 2016; Revised: 1 ${ }^{\text {st }}$ October 2016; Accepted: $18^{\text {th }}$ October 2016

\begin{abstract}
Producing transportation fuels from bio sources was of prime importance due to the strict environmental legislations for producing clean fuels from conventional oil resources. However, the economical impacts of the biofuel production should be considered. In this study, the production of bio-naphtha and biodiesel from palm oil using homogeneous catalyst, i.e. an aqueous phase of ammonium molybdate, was studied. This catalyst was prepared by dissolving sodium molybdate in de-ionized water with hydrochloric acid, and then neutralizing the mixture with ammonium hydroxide. The solution was dried at $90^{\circ} \mathrm{C}$ for $24 \mathrm{~h}$ to obtain ammonium molybdate. Then, characterization of the catalyst was done by informative techniques, such as XRD and FT-IR. The results showed that the main phase of the synthesized catalyst was molybdate ammonium hydrates $\left(4 \mathrm{MoO}_{3} \cdot 2 \mathrm{NH}_{3} . \mathrm{H}_{2} \mathrm{O}\right)$, and also bands of $\mathrm{Mo}-\mathrm{O}$, Mo-O-Mo, N-H and surface hydroxyl groups were observed in the sample. Moreover, activity test confirms that the bio-naphtha produced from the proposed method has a few aromatic components, and its sulfur content was negligible. Moreover, ash, nitrogen, sulfur and carbon residue were not detected in the produced biodiesel, and its Cetane index was 66.3. Therefore, it was a suitable fuel for diesel engines vehicles. Copyright $@ 2017$ BCREC GROUP. All rights reserved
\end{abstract}

Keywords: biodiesel; palm oil; ammonium molybdate; hydrogenation; catalyst

How to Cite: Sadighi, S., Targhi, S.K.M. (2017). Preparation of Biofuel from Palm Oil Catalyzed by Ammonium Molybdate in Homogeneous Phase. Bulletin of Chemical Reaction Engineering \& Catalysis, 12 (1): 49-54 (doi:10.9767/bcrec.12.1.486.49-54)

Permalink/DOI: http://dx.doi.org/10.9767/bcrec.12.1.486.49-54

\section{Introduction}

Nowadays, due to the stringent environmental legislations, it is mandatory to produce clean fuels, and therefore renewable energy sources and modern technologies are needed which is also expected to overcome the energy fossil limitation issues. One of alternatives is biodiesel which can reduce dependence on fossil fuels [1]. However from economics point of view, the biodiesel is not comparable with the petroleum based diesel due to its high produc-

\footnotetext{
* Corresponding Author.
}

E-mail: sadighis@ripi.ir tion cost and feed-stock price [2]. The required raw materials can be obtained from a wide variety of bio sources; however, technical and economic feasibility, environmental effects, accessibility and national policy concerns must also be considered [3]. Vegetable oils manufactured from crops such as palm, jatropha, soybean, rapeseed, and residues can be used for producing bio diesel [4]. In recent years, biodiesel produced from palm oil has been identified as a renewable energy source with huge potential in the future [5].

There are four primary methods to make biodiesel, i.e. blending, microemulsion, cracking and transesterification. In the latter 
method, the transesterification of triglycerides (vegetable oil and animal fats) with alcohol is carried out in the presence of a catalyst where the triglycerides in the vegetable oil with alcohol form a mixture of fatty acid alkyl esters and glycerol [6]. This process is catalyzed by catalysts with both acidic and basic sites in the homogeneous or heterogeneous phases [7-8]. However, mineral chemical catalysts have some unavoidable drawbacks, such as environmental pollution and methanol consumption, a large amount of alkaline wastewater products and difficulties in catalyst recovery and reuse [9-10]. These problems can be solved by using some new heterogeneous catalysts such as solid acids, resins, or zeolites in transesterification [11-14]. But, all these processes and catalysts still have some problems related to environmental safety, catalyst recyclability, and also disposal of the spent catalyst [15].

The other common method which is applied to produce biofuel from vegetable oil is thermal cracking and hydrogenation of vegetable oil in different reaction conditions and catalysts [1622]. Based on our knowledge, hydroconversion of vegetable oil using Mo-based catalyst in the homogeneous aqueous phase is not reported in the previous researches. This article provides the production of biofuels from palm oil using a hydrogenation process in the presence of an emulsion homogeneous catalyst complex comprising an aqueous mixture of ammonium molybdate.

\section{Materials and Method}

\subsection{Feed stock and catalyst preparation}

To prepare catalyst, at first $1.2 \mathrm{~g}$ of commercial sodium molybdate with the purity of $98 \%$ is dissolved into minimum amount of de-ionized water $(5 \mathrm{~mL})$. Then, $5 \mathrm{~mL}$ of hydrochloric acid (purchased from Merck Company, Cat. No. 1003178) is added to this mixture to meet the $\mathrm{pH}$ value of 2 ; therefore, sodium molybdate is converted to chloride salts as follows:

$$
\mathrm{Na}_{2} \mathrm{MoO}_{4}+8 \mathrm{HCl}(\mathrm{aq}) \rightarrow 2 \mathrm{NaCl}+\mathrm{MoCl}_{6}+4 \mathrm{H}_{2} \mathrm{O}
$$

The resulted solution is gradually neutralized with $2.5 \mathrm{~mL}$ of ammonium hydroxide solution (purchased from Sigma-Aldrich Company CAS No. 1336-21-6) to reach the $\mathrm{pH}$ value of about 11. This solution is heated to $90^{\circ} \mathrm{C}$, and kept for $24 \mathrm{~h}$ at this condition to produce ammonium molybdate as follows:

$$
\begin{gathered}
\mathrm{MoCl}_{6}+3 \mathrm{NH}_{4} \mathrm{OH}(\mathrm{aq}) \rightarrow\left(\mathrm{NH}_{4}\right)_{2} \mathrm{MoO}_{4}+\mathrm{NH}_{4} \mathrm{Cl}(\mathrm{aq}) \\
\text { ammonium molybdates }
\end{gathered}
$$

After $24 \mathrm{~h}$, the mixture is filtered, and the cake is washed three times with the de-ionized water; then, it is dried for $48 \mathrm{~h}$ at the room temperature. For performing the activity test, this synthesized solid catalyst is dissolved in the de-ionized water, and is used as the homogeneous catalyst phase for the hydrogenation of palm oil.

To determine the structure of this catalyst, Philips X-ray diffractometer model PW 1840 (APD - software package and JCPDF - search files) is used. The data obtained were evaluated by ASTM D3942 and D5357 test methods. The Fourier transform infrared spectroscopy (FT-IR) of the catalyst was measured using a Vertex 70 (Bruker) device. Moreover, Anton Paar Viscometer (model SVM 3000) was used for measuring viscosity of feed and products according to ASTM 445 test procedure. All required densities were measured using ASTM 5002 standard method.

\subsection{Pilot plant test}

To study the activity of the hydrogenation catalyst to produce biodiesel from palm oil (see Table 1), experiments were conducted in a batch reactor. The simplified process flow diagram of the hydroconverting process is presented in Figure 1. The hydroprocessing reactions are performed under the hydrogen pressure of 70 barg, temperature of $450{ }^{\circ} \mathrm{C}$, hydrogen to hydrocarbon ratio of 500 , and the resi-

Table 1. Specifications of the palm oil used for hydroconversion process

\begin{tabular}{cc}
\hline Indices and units & $\begin{array}{c}\text { Feed } \\
\text { specification }\end{array}$ \\
\hline Specific gravity @ $15^{\circ} \mathrm{C}$ & 0.92 \\
Refractive index @ $50^{\circ} \mathrm{C}$ & 1.453 \\
Saponification value, $\mathrm{mg} \mathrm{KOH} / \mathrm{g}$ oil & 199 \\
Iodine number & 52.4 \\
\hline True Boiling Point Data \\
\hline Volume $\%$ & Temp $\left({ }^{\circ} \mathrm{C}\right)$ \\
\hline IBP & 240 \\
5 & 380 \\
10 & 450 \\
20 & 470 \\
30 & 500 \\
40 & 520 \\
50 & 540 \\
60 & 570 \\
70 & 615 \\
80 & 655 \\
90 & 730 \\
95 & 790 \\
FBP & 840 \\
\hline
\end{tabular}


dence time of $30 \mathrm{~min}$. This process is protected by a US Patent (7585406 B2) [23].

To perform the activity test, at first the homogeneous phase of the catalyst should be prepared. Therefore, $1.1 \mathrm{~g}$ of the synthesized solid catalyst (see Section 2.1) is added to $10 \mathrm{ml}$ of de-ionized water. This mixture is dispersed with the mixing rate of $400 \mathrm{rpm}$ at $50{ }^{\circ} \mathrm{C}$ for 30 $\mathrm{min}$. Then, $1000 \mathrm{~g}$ of palm oil is mixed with the prepared homogeneous aqueous catalyst phase in the reactor at the room temperature. Then, all input and output valves (see Figure 1) of the reactor are closed, and the reactant is agitated for $30 \mathrm{~min}$ with the rate of $1000 \mathrm{rpm}$ to prepare a homogeneous aqueous phase. During the agitation, the temperature increases only up to $200{ }^{\circ} \mathrm{C}$ to prevent from initiating hydrocracking reactions. Then, the required hydrogen is injected to the reactor from the feed line, and the temperature of the reactor increases to $450{ }^{\circ} \mathrm{C}$ during $50 \mathrm{~min}$. After this point, hydroconversion reactions are carried out for $30 \mathrm{~min}$ under the pressure of 70 barg. Finally, heating system is promptly shut down, and hydrogen gas is injected to the reactor to cool down the reactant.

\section{Results and Discussion}

\subsection{Characterization of hydrogenation catalyst}

In Figure 2, the XRD patterns of the precursor and the synthesized catalyst are presented. From Figure 2a, it can be concluded that the phase of the commercial sodium ammonium molybdate is $\mathrm{NaNH}_{4} \mathrm{Mo}_{3} \mathrm{O}_{10} \cdot \mathrm{H}_{2} \mathrm{O}$ (JCPDS No. 36-335). Moreover, according to the XRD pattern of the catalyst (see Figure $2 b$ ), the main

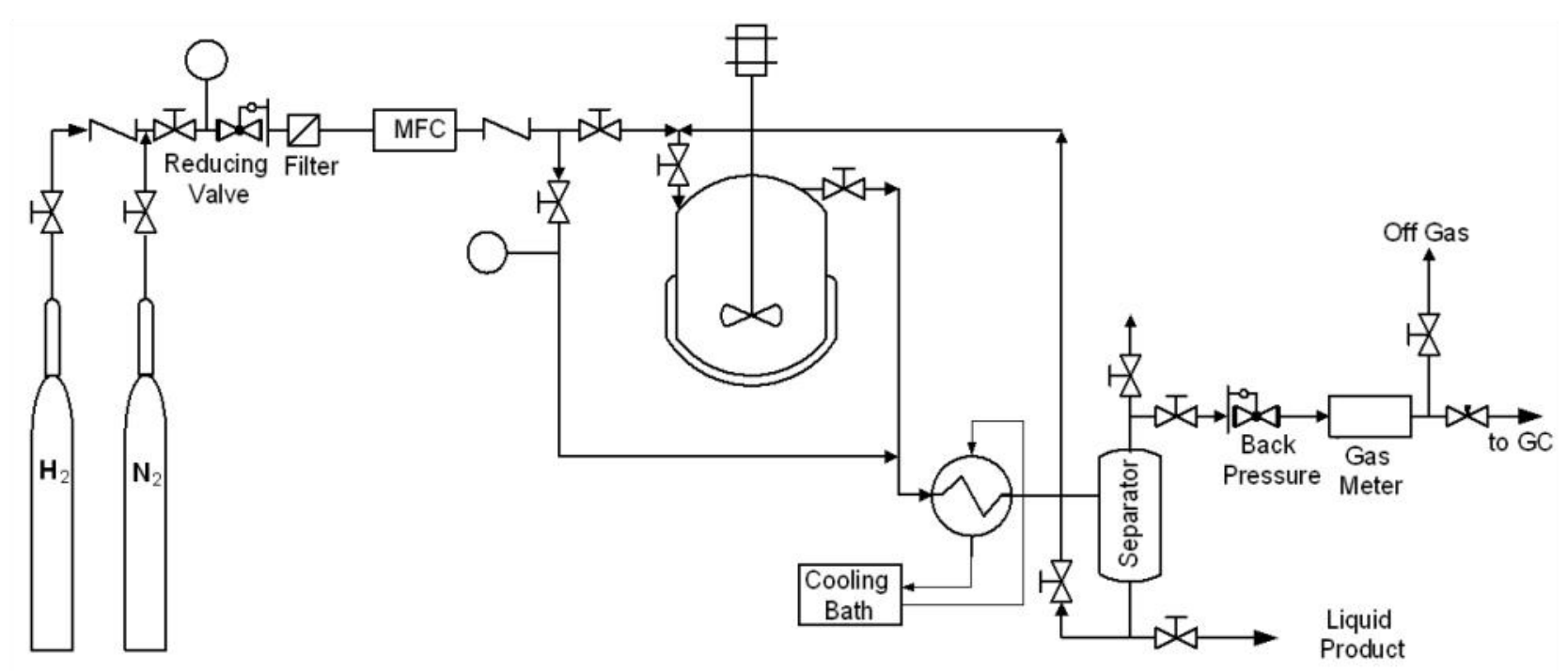

Figure 1. Flow diagram of pilot scale hydroconversion process

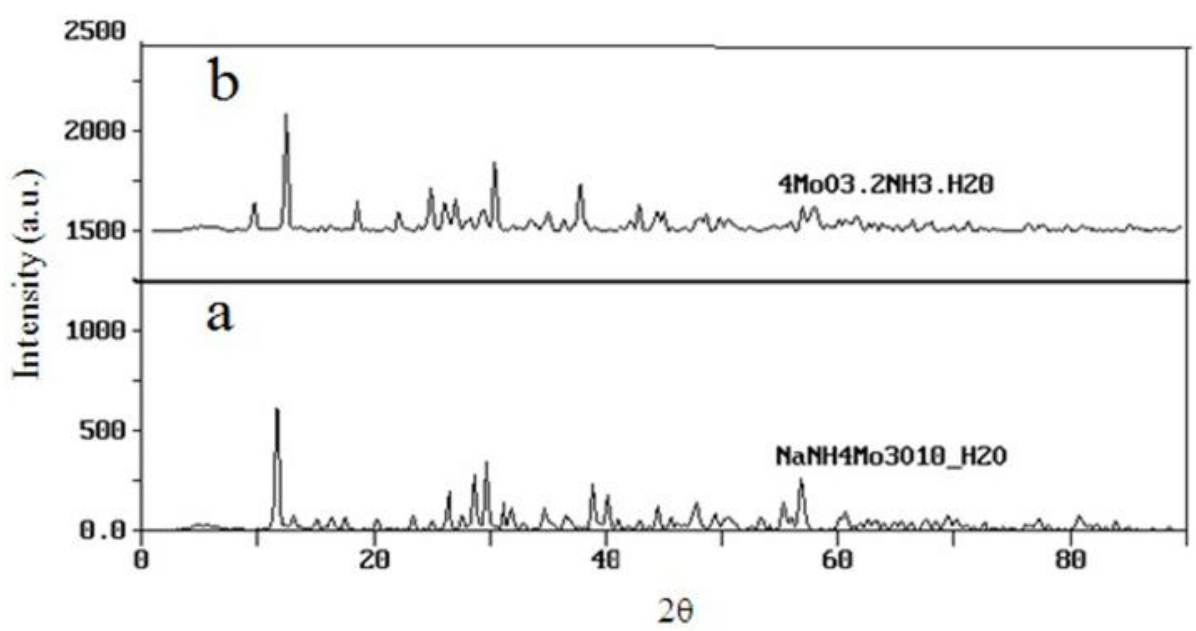

Figure 2. XRD analysis of commercial sodium ammonium molybdate (a), and synthesized molybdate ammonium hydrate (b) 
ingredient of the synthesized hydroconverting catalyst is $4 \mathrm{MoO}_{3} .2 \mathrm{NH}_{3} . \mathrm{H}_{2} \mathrm{O}$ (JCPDS No. 21570).

In Figure 3, the FT-IR spectrum of the synthesized ammonium molybdate is presented. Vibrations at bands 620,880 and $990 \mathrm{~cm}^{-1}$ represent stretching of $\mathrm{Mo}-\mathrm{O}$ bond and stretching and bending bonds of Mo-O-Mo, respectively. The bands at $3156-3163 \mathrm{~cm}^{-1}$ and $3400 \mathrm{~cm}^{-1} \mathrm{can}$ be assigned to stretching of $\mathrm{N}-\mathrm{H}$ bond and surface hydroxyl groups of the sample, respectively [24-25].

From Figures 2 and 3, it can be concluded that $\mathrm{Na}$ atoms are eliminated from the structure of the synthesized catalyst. Therefore, high carbon content species and light cracked gases could be reduced during the proposed process [26]. After hydroconverting palm oil, no coke was detected on the outer surface of the reactor. Moreover, a low yield of cracked gases (less than $5 \mathrm{wt} \%$ ) was observed under the reaction condition. It was supposed that these results were mainly attributed to $\mathrm{Na}$ elimination from the structure of the catalyst.

\subsection{True boiling point (TBP) curve of the product}

After performing the hydroconversion process under mentioned conditions (Section 2.1), the TBP curve of the feed and product are shown in Figure 4. To confirm the repeatability of the result, the hydroconversion of palm oil was performed three times under the same conditions which were called H1, H2 and H3. From this figure, it can be found that using the proposed method, about 13.5, 51.5, and 43 volume $\%$ of the palm oil can be converted to products in the boiling point range of naphtha $\left(50-180{ }^{\circ} \mathrm{C}\right)$, diesel $\left(180-350{ }^{\circ} \mathrm{C}\right)$ and heavy gas oil $\left(350-520{ }^{\circ} \mathrm{C}\right)$, respectively. The water content of the product was less than 1.5 vol.\%. Moreover, the specific gravity of the product was 0.85 .

According to the literature, there are three main fatty acid molecules in the palm oil triglyceride i.e. miristic acids $\left(\mathrm{C}_{14}\right)$ that have no double bond in the structure, palmitic acids $\left(\mathrm{C}_{16}\right)$ also with no double bond, and oleic acids $\left(\mathrm{C}_{18}\right)$ that have one double bond in the middle of the carbon chain [27]. Therefore, it is supposed that during hydroconversion of palm oil, cracking reactions converts long chains of palmitic, oleic and miristic acids to the smaller ones to produce smaller molecules.

\subsection{Specifications of the bio-naphtha}

The produced naphtha from hydroconversion of the palm oil had the specific gravity of

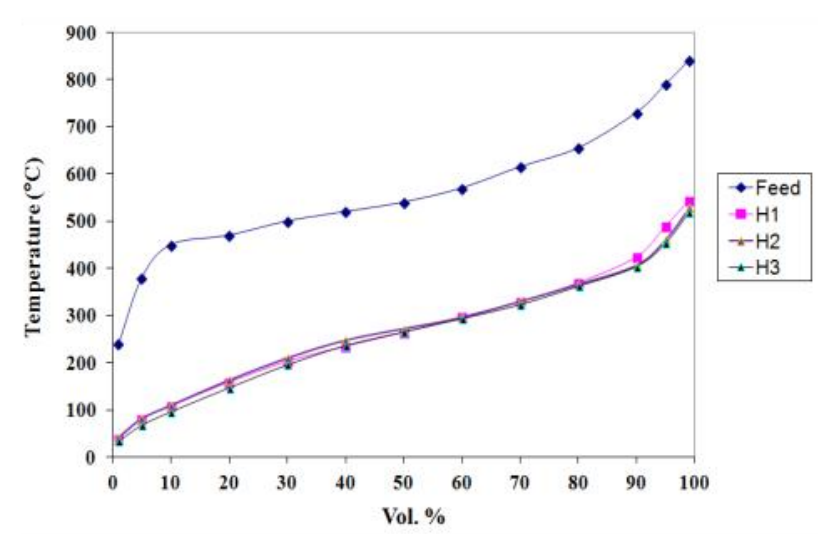

Figure 4. True boiling point (TBP) curve of palm oil feed and hydroconversion product

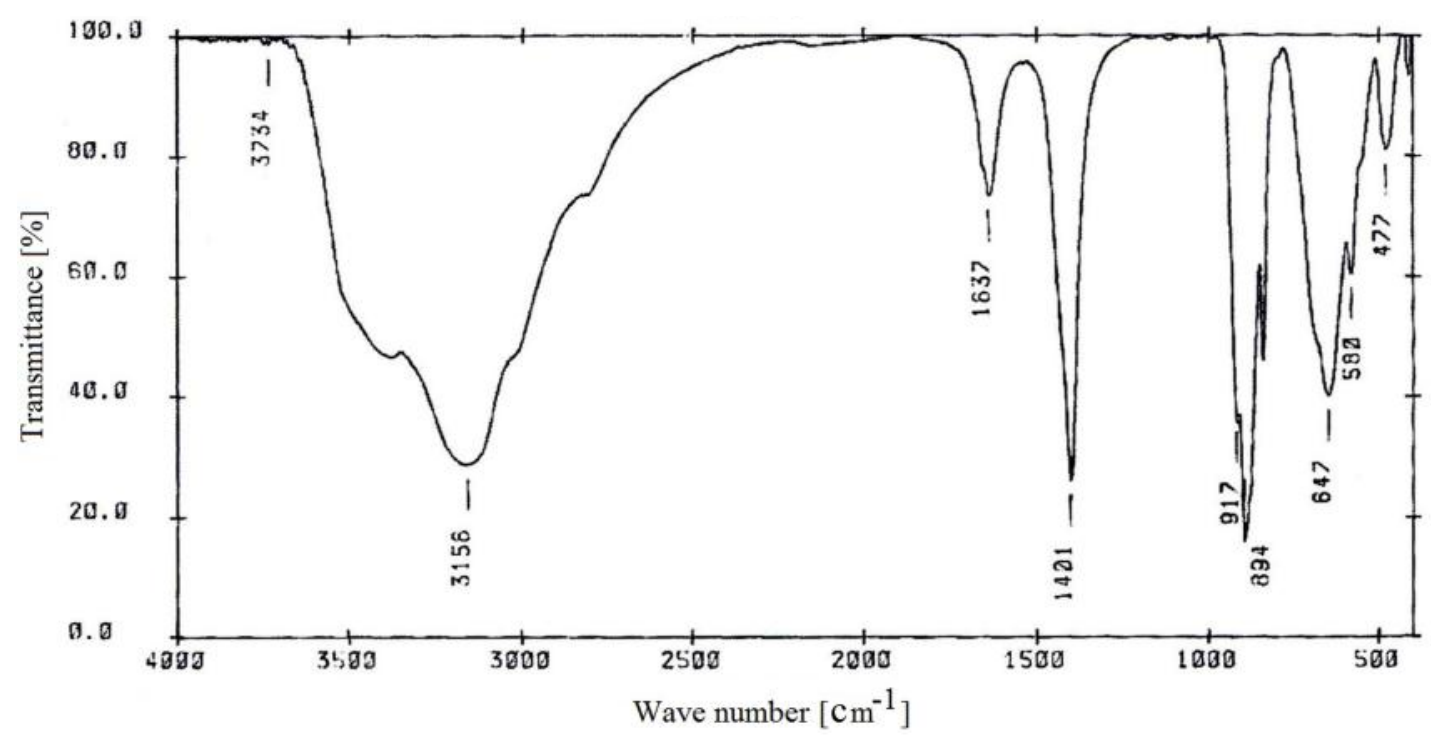

Figure 3. FT-IR spectrum of homogeneous ammonium molybdate catalyst 
0.76. Moreover, the PONA analysis showed that the aromatic, olefin and paraffin content of the naphtha were $7.9,0.29$ and 91.5 wt.\%, respectively; but, the sulfur and nitrogen content of that were negligible. Furthermore, the RON index of this product was about 51.8. From these results, it is concluded that the produced bio-naphtha cannot be directly used as a motor fuel, and other finishing processes such as catalytic reforming should be provided.

\subsection{Specifications of the biodiesel}

The produced biodiesel from hydroconversion of the palm oil had the specific gravity and flash point of 0.8 and $88^{\circ} \mathrm{C}$, respectively. Moreover, the kinematic viscosity at $40{ }^{\circ} \mathrm{C}$ and Cetane index of this product were $3.01 \mathrm{cSt}$ and 66.3, respectively. No ash, nitrogen, sulfur and carbon residue was observed in the produced biodiesel. Moreover, saturate and aromatic contents of the diesel were $74.9 \mathrm{wt} \%$ and $15.1 \mathrm{wt} \%$, respectively. Based on the EN 590 (published by the European Committee for Standardization, Euro 6-2014), the lower Cetane index and the upper final boiling point of diesel are 46 and $360{ }^{\circ} \mathrm{C}$, respectively, with a sulfur content less than 10 ppm (wt). Moreover, the kinematic viscosity of such fuel should be in the range between 2 and 4.5 cSt. Thus, the biodiesel produced from the hydroconversion of palm oil is a good candidate to be used as a premium blending fuel in the diesel pool of a refinery.

\subsection{Specifications of the bio-heavy gas oil (350-520 $\left.{ }^{\circ} \mathrm{C}\right)$}

The produced bio-heavy gas oil had the specific gravity and pour point of 0.875 and $31^{\circ} \mathrm{C}$, respectively. Moreover, the kinematic viscosity of this product at $40{ }^{\circ} \mathrm{C}$ and $100{ }^{\circ} \mathrm{C}$ were 17.39 and $4.32 \mathrm{cSt}$, respectively. No ash, nitrogen and sulfur were observed in this product; but, the carbon content of that was about $0.04 \mathrm{wt} \%$. It is supposed that the bio-heavy gas oil produced from the hydroconversion of palm oil is a suitable feed for the vacuum gas oil hydrocracker unit in a refinery to be converted to naphtha and diesel.

\section{Conclusions}

Palm oil was successfully hydroconverted to bio-naphtha, biodiesel and bio-heavy gas oil using an aqueous ammonium molybdate catalyst in a homogeneous phase. XRD patterns of the prepared catalyst showed that the main component of the precursor was sodium ammonium molybdate. Additionally, the structure of cata- lyst was composed of molybdate ammonium hydrates, and also $\mathrm{Na}$ atoms were eliminated from the structure of catalyst. The FT-IR spectrum of the catalyst indicated the appearance of Mo-O, N-H, Mo-O-Mo bonds and surface hydroxyl groups.

According to the hydroconverting experiments in a batch reactor, it was concluded that the produced biodiesel from palm oil had an acceptable specification for being used as a blending fuel in the diesel pool. However, bionaphtha should be pre-processed before using as a motor fuel. Moreover, the bio-heavy oil attained in the proposed process was a good feed for the vacuum gas oil hydrocracker in a crude oil refinery to produce clean naphtha and diesel.

\section{Acknowledgements}

The authors thank to research institute of petroleum industry (RIPI) for supporting this project (Project No: 11310426).

\section{References}

[1] Hadiyanto, H., Lestari, S.P., Widayat, W. (2016). Preparation and Characterization of Anadara Granosa Shells and $\mathrm{CaCO}_{3}$ as Heterogeneous Catalyst for Biodiesel Production. Bulletin of Chemical Reaction Engineering \& Catalysis, 11(1): 21-26.

[2] Istadi, I., Mabruro, U., Kalimantini, B.A., Buchori, L., Anggoro, D.D. (2016). Reusability and Stability Tests of Calcium Oxide Based Catalyst $\left(\mathrm{K}_{2} \mathrm{O} / \mathrm{CaO}-\mathrm{ZnO}\right)$ for Transesterification of Soybean Oil to Biodiesel. Bulletin of Chemical Reaction Engineering \& Catalysis, 11(1): 34-39.

[3] Fang, D., Hiang, C., Yang, J. (2013). Preparation of Biodiesel from Caster Oil Catalyzed by Novel Basic Ionic Liquid. Energy Technology, 1: 135-138.

[4] El-Adawy, M., Ibrahim, A., El-Kassaby, M.M. (2013). An Experimental Evaluation of using Waste Cooking Oil Biodiesel in a Diesel Engine. Energy Technology, 1: 726-734.

[5] Koh, M.Y., Ghazi, M.T.I. (2011). A Review of Biodiesel Production from Jatropha Curcas L. Oil. Renewable and Sustainable Energy Reviews, 15: 2240-2251.

[6] Mekhilef, S., Siga, S., Saidur, R. (2011). A Review on Palm Oil Biodiesel as a Source of Renewable Fuel. Renewable and Sustainable Energy Reviews, 15: 1937-1949.

[7] Kansedo, J., Lee, K.T., Bhatia, S. (2008). Feasibility of Palm Oil as the Feedstock for Biodiesel Production via Heterogeneous Trans- 
esterification. Chemical Engineering Techno$\log y, 31(7)$ : 993-999.

[8] Vicente, G., Martınez, M., Aracil, J.E. (2004). Integrated Biodiesel Production: A Comparison of Different Homogeneous Catalysts Systems. Bioresource Technology, 92(3): 297-305.

[9] Haas, M.J., Michalski, P.J., Runyon, S., Nunez, A., Scott, K.M. (2003). The Production of Fatty Acid Methyl Esters from Acid Oil, a Byproduct of Vegetable Oil Refining. Journal of the American Oil Chemists' Society, 80: 97102.

[10] He, Q., Xu, Y., Teng, Y., Wang, D. (2008). Biodiesel Production Catalyzed by Whole-Cell Lipase from Rhizopus chinesis. Chinese Journal of Catalysis, 29: 41-44.

[11] Kouzu, M., Kasuno, T., Tajika, M., Sugimoto, Y., Yamanaka, S., Hidaka, J. (2008). Calcium Oxide as a Solid Base Catalyst for Transesterification of Soybean Oil and its Application for Biodiesel Production. Fuel, 87: 27982806.

[12] Dos Reis, S.C.M., Lachter, E.R., Nascimento, R.S.V., Rodrigues Júnior, J.A., Reid, M.J. (2005). Transesterification of Brazilian Vegetable Oils with Methanol over Ion-exchange Resins. Journal of the American Oil Chemists' Society, 82: 661-665.

[13] Feng, Y., He, B., Cao, Y., Li, J., Liu, M., Yan, F., Liang X. (2010). Biodiesel Production using Cation-exchange Resin as Heterogeneous Catalyst. Bioresource Technology, 101: 15181521.

[14] Narasimharao, K., Brown, D.R., Lee, A.F., Newman, A.D., Siril, P.F., Tavener, S.J., Wilson, K. (2007). Structure-activity Relations in Cs-doped Heteropolyacid Catalysts for Biodiesel Production. Journal of Catalysis, 248: 226-234.

[15] Yanfei, H., Xiaoxiang, H., Qing, C., Lingxiao, Z. (2013). Transesterification of Soybean Oil to Biodiesel by Bronsted-Type Ionic Liquid Acid Catalysts. Chemical Engineering Technology, 36(9):1559-1567.

[16] Tamunaidu, P., Bhatia, S. (2007). Catalytic Cracking of Palm Oil for the Production of Biofuels: Optimization Studies. Bioresource Technology, 98(18): 3593-3601.

[17] Siswanto, D.Y., Salim, G.Y., Wibisono, N., Hindarso, H., Sudaryanto, Y., Ismadji, S. (2008). Gasoline Production from Palm oil via Catalytic Cracking Using MCM-41: Determination of Optimum Condition. ARPN Journal of Engineering and Applied Sciences, 3(6): 4246.
[18] Roesyadi, A., Hariprajitno, D., Nurjannah, N., Savitri, S.D. (2013). HZSM-5 Catalyst for Cracking Palm Oil to Gasoline: A Comparative Study with and without Impregnation. Bulletin of Chemical Reaction Engineering \& Catalysis, 7(3): 185-190.

[19] Twaiq, F., Al-Anbari, I., Nasser, M. (2013). Kinetics of Palm Oil Cracking in Batch Reactor. World Academy of Science, Engineering and Technology, 7(1): 9-13.

[20] Yang, S.C., Chang, J.R., Lee, M.T., Lin, T.B., Lee, F.B., Hong, C.T., Lee, J.C., (2014). Homogeneous Catalysts for Biodiesel Production, US 8624073.

[21] Ahmad, M., Farhana, R., Abdul Raman, A.A., Bhargava, S.K. (2016). Synthesis and Activity Evaluation of Heterometallic Nano Oxides Integrated ZSM-5 Catalysts for Palm Oil Cracking to Produce Biogasoline. Energy Conversion and Management, 119: 352-360.

[22] Abbasov, V., Mammadova, T., Aliyevaa, T., Abbasova, M., Movsumova, N., Jushi, A., Lvov, A., Abdullayev, E. (2016). Catalytic Cracking of Vegetable Oils and Vacuum Gasoil with Commercial High Alumina Zeolite and Halloysite Nanotubes for Biofuel Production. Fuel, 181: 55-63.

[23] Kadiev, K.M., Mezhidov, V.K., Zarkesh, J., Hashemi, R., Masoudian, S.K., (2009). Process for Hydroconvering of a Heavy Hydrocarbonaceous Feedstock, US 7585406 B2.

[24] Arandiyan, H.R., Parvari, M. (2008). Prepararion of La-Mo-V Mixed-oxide Systems and their Application in the Direct Synthesis of Acetic Acid. Journal of Natural Gas Chemistry, 17: 213-224.

[25] Miao, Y., Lu, G. (2009). Effects of Preparation Procedure in Sol-gel Method on Performance of $\mathrm{MoO}_{3} / \mathrm{SiO}_{2}$ Catalyst for Liquid Phase Epoxidation of Propylene with Cumene Hydroperoxide. Journal of Molecular Catalysis A: Chemical, 306: 17-22.

[26] Masoudian, S.K., Sadighi, S., Tofigh, A. Khodadadi, Z. (2014). Upgrading Extra Heavy Oil Using Technical Grade Sodium Molybdate. Journal of Applied Researches in Chemistry, 7(4): 39-45.

[27] Nasikin, M., Susanto, H.B., Hirsaman, M.A., Wijanarko, A. (2009). Biogasoline from Palm Oil by Simultaneous Cracking and Hydrogenation Reaction over Nimo/zeolite Catalyst. World Applied Sciences Journal (Special Issue for Environment), 5: 74-79. 